\title{
Growth performance and wood quality of white jabon (Neolamarckia cadamba) progeny testing at Parung Panjang, Bogor, Indonesia
}

\author{
NURUL CHAERANI ${ }^{1, \bullet}$, DEDE J SUDRAJAT ${ }^{2}$, ISKANDAR Z SIREGAR ${ }^{3}$, ULFAH J SIREGAR ${ }^{3, \bullet \bullet}$ \\ ${ }^{1}$ Tropical Silviculture Program, Graduate School, Institut Pertanian Bogor. Jl. Ulin, Kampus IPB Dramaga, Bogor 16680, West Java, Indonesia. \\ Tel./fax.+62-812-92843642, `email: nchaeranisvk53@gmail.com. \\ ${ }^{2}$ Forest Tree Seed Technology Research and Development Center. J1. Pakuan Ciheuleut PO BOX 105 Bogor 16143, Indonesia \\ ${ }^{3}$ Department of Silviculture, Faculty of Forestry. Institut Pertanian Bogor. J1. Ulin Kampus IPB Dramaga, Bogor 16680, West Java, Indonesia. \\ Tel./fax. +62-812-1062154, ^vemail: siregaruj@gmail.com.
}

Manuscript received: 30 June 2019. Revision accepted: 24 July 2019.

\begin{abstract}
Chaerani N, Sudrajat DJ, Siregar IZ, Siregar UJ. 2019. Growth performance and wood quality of white jabon (Neolamarckia cadamba) progeny testing at Parung Panjang, Bogor, Indonesia. Biodiversitas 20: 2295-2301. The aim of this study was to evaluate the genetic parameters of growth and wood quality in white jabon progeny test at 54 months old in Parung Panjang, Bogor. The 105 half-sib families obtained from 12 provenances were evaluated in a randomized complete block design with five replications. Wood quality was assessed both in a non-destructive way using a pilodyn and by destructive method using wood sample taker. Results indicated that the mean value ranged from 5.10 to $10.15 \mathrm{~m}$ for height, 6.67 to $15.30 \mathrm{~cm}$ for diameter, 2.30 to $3.62 \mathrm{~cm}$ for pilodyn penetration, 0.66 to 0.82 $\mathrm{g} / \mathrm{cm} 3$ for wood density, 0.33 to 0.50 for specific gravity, and 66 to $111 \%$ for moisture content, respectively. There were significant differences among 105 families for all traits except moisture content. The high heritability estimate was found for height (0.4-0.69) and basic density (0.27-0.59). Applying $80 \%$ selection intensity on diameter and leaving 84 best families in each block will produce a high total genetic gain. Pilodyn penetration had negative correlation with diameter, wood density, and specific gravity.
\end{abstract}

Keywords: Genetic gain, heritability, pilodyn penetration, progeny test, white jabon

\section{INTRODUCTION}

White jabon (Neolamarckia cadamba (Roxb.) Bosser) is one of the fast-growing species which can be developed for plantation and community forest (Kallio et al. 2011; Irawan and Purwanto 2014). This species has been widely planted in Indonesia especially in Java and East Kalimantan (Fox 1971). The wood can be used as pulp production, packing box (Hartanto 2011), and fuel (Gultom et al. 2017). According to Gultom et al. (2017), 100\% jabon waste materials made into charcoal can have a calorific value more than $6000 \mathrm{ccal} / \mathrm{g}$. Until now the development of white jabon in plantation and community forest has not used superior seeds. Burger (2009) and Yudohartono (2013) stated that plants growth is determined not only by quality of the site and proper silvicultural treatment, they are also influenced by the quality of seeds. Improving the quality of seeds can be achieved through breeding program by building seed sources that produce seeds with superior genetic characters (Langga et al. 2012). The Forest Tree Seed Technology Research and Development Center of Ministry of Environment and Forestry, Indonesia (BPTPTH) has collaborated with Faculty of Forestry, IPB University, and SEAMEO BIOTROP to establish a progeny test of white jabon in 2013, located in Parung Panjang, Bogor. The test involved 105 families from 12 provenances originated from seven Indonesian islands (Sudrajat et al. 2016).

Periodical evaluation of the progeny test is necessary for determining the growth and genetic parameters, such as heritability of growth characteristics and their genetic correlation (Pathauer et al. 2004). The progeny test could then be converted into a seed orchard by applying a selection. Growth traits such as height and diameter can be used as criteria for getting superior genotypes. To date selection program to obtain superior genotypes has combined characteristics of growth with wood quality, such as moisture content, wood density and specific gravity (Gaspar et al. 2009; Martinez-Meier 2011; Nocetti et al. 2012; Muga et al. 2014). Several studies have shown a significant correlation between growth and wood quality, such as in Gmelina arborea Roxb. (Moya and Tomazello 2007), but other studies have reported the opposite such as in Eucalyptus camaldulensis Dehnh. (Malik and Abdelgadir 2015). Growth and wood quality are important parameters for choosing superior genotypes. However, there are still limited genetic trials in Indonesia that have evaluated the performance based on both parameters of growth and wood quality, including for jabon and other fast-growing species (FGS).

In the present study, growth traits (height and diameter) and wood quality (pilodyn penetration, wood density, specific gravity, and moisture content) were analyzed in individuals within-family and among family levels in 5 blocks of white jabon progeny test at 54 months in Parung Panjang, Bogor, Indonesia. Heritability, genetic gain, and genetic correlations would be applied on conversion of the progeny test to seedling seed orchard by way of thinning to select the best individual within-family and family levels for solid (construction) wood properties. 


\section{MATERIALS AND METHODS}

\section{Study area}

The progeny test was established at Parung Panjang Forest Research Station, Bogor District, West Java, Indonesia $\left(06^{\circ} 20^{\prime} 42^{\prime \prime} \mathrm{S}, 106^{\circ} 06^{\prime} 15^{\prime \prime} \mathrm{E}\right.$, altitude of $52 \mathrm{~m}$ asl) in February 2013. The annual mean temperature is $28^{\circ} \mathrm{C}$ and annual mean rainfall is $2440 \mathrm{~mm} /$ years. The soil had low level of N, P, K and C-organic with $\mathrm{pH}$ of 4.2 (Sudrajat et al. 2016). The progeny test was designed in randomized complete block design (RCBD) with 5 blocks (replications). The planting had a spacing of $3 \mathrm{~m} \times 3 \mathrm{~m}$ with 4-tree row plot (Sudrajat et al. 2016). The trial includes 105 families from 12 provenances and information on the geographical locations were presented in Table 1.

\section{Procedures}

Diameter at breast height (DBH $1.3 \mathrm{~m}$ ) and height of all trees in the tests were recorded. Wood quality was assessed with a non-destructive method using a pilodyn penetration (Greaves et al. 1996; Hansen 2000; Jun et al. 2010) and destructive method using sample cores (Muga et al. 2014). Pilodyn penetration was measured using a $6 \mathrm{~J}$ Forest Pilodyn at $1.3 \mathrm{~m}$ above the ground, shot 3 (three) times per tree, then averaged. Wood samples sized $1-2 \mathrm{~cm}$ were taken using increment cores at $1.3 \mathrm{~m}$ height, and immediately stored in plastic tubes with both ends sealed. The samples were weighed for green biomass and the volume was determined by the Archimedes principle, then dried in oven at $105^{\circ} \mathrm{C}$ for 24 hours to get the dry biomass. Wood density $(\rho)$, specific gravity, and moisture content were calculated (Kien et al. 2008) as follows:

$$
\begin{aligned}
& \rho\left(\text { Wood density }\left(\mathrm{g} / \mathrm{cm}^{2}\right)=\frac{\text { Green biomass }(g)}{\text { Volume }\left(\mathrm{cm}^{2}\right)}\right. \\
& \text { Specific gravity }=\frac{\text { Dry biomass } / \text { volume }}{\text { Water density }} \\
& \text { Moisture content }=\frac{\text { Green biomass }- \text { dry biomass }}{\text { dry biomass }} \times 100
\end{aligned}
$$

\section{Data analysis}

Analysis of variance (ANOVA) was performed using SAS 9.4 for all parameters using the following statistical model:

$$
\mathrm{Y}_{\mathrm{ijk}}=\mathrm{m}+\mathrm{F}_{\mathrm{i}}+\mathrm{Bj}+\mathrm{E}_{\mathrm{ijk}}
$$

Where Yijk $=\mathrm{k}^{\text {th }}$ observation $(\mathrm{k}=1,2,3,4)$ at $\mathrm{i}^{\text {th }}$ family $(i=1,2, . .105)$ in $\mathrm{j}^{\text {th }}$ block $(\mathrm{j}=1,2,3,4,5) ; \mathrm{m}=$ mean value; $\mathrm{Fi}=$ Effect of $i^{\text {th }}$ family $(i=1,2, . .105) ; B j=$ effect of $j^{\text {th }}$ block $(\mathrm{j}=1,2,3,4,5)$; Eijk $=$ error.

\section{Genetic parameters}

Heritability was estimated from the variance components as described in Falconer and Mackay (1996). Narrow sense individual and family heritability for each parameter were estimated using equations:

$$
h^{2} i=\frac{\sigma^{2} \mathrm{~A}}{\sigma^{2} \mathrm{U}}=\frac{4 \sigma^{2} \mathrm{~F}(\mathbb{P})}{\sigma^{2} \mathrm{U}} ; h^{2} f=\frac{\sigma^{2} \mathrm{~F}(\mathbb{P})}{\sigma^{2} f m}
$$

Where $h^{2} i=$ individual heritability, $\sigma^{2} \mathrm{~A}=$ additive genetic variance, $4 \sigma^{2} \mathrm{~F}(\mathrm{P})=$ between-family within provenance variance component, $\sigma^{2} \mathrm{U}=$ phenotypic variance calculated as, $\sigma^{2} U=4 \sigma^{2} F(P)+4 \sigma^{2} R F(P)+\sigma^{2} e$, where $\sigma^{2} \mathrm{~F}(\mathrm{P})=$ variance due to interaction between replication and family within provenance (experimental error), $\sigma^{2} \mathrm{e}=$ variance among individual trees within family (sampling error), $h^{2} f=$ family heritability, $\sigma^{2} f m=$ family phenotype variance, calculated as $\sigma^{2} f m=\sigma^{2} F(P)+$ $\left(k_{2} / k_{3}\right) \quad \sigma^{2} \quad R F(P)+(1 / k 3) \quad \sigma^{2} \quad e$, where $k_{2}$ and $k_{3}=$ respectively, coefficients for $\sigma^{2} \mathrm{RF}(\mathrm{P})$ and $\sigma^{2} \mathrm{~F}(\mathrm{P})$ in the expected mean squares.

Genetic gain, which is a parameter that is useful to determine the success level, was calculated by Falconer's (1981) formula:

$$
\mathrm{KGH}=\mathrm{i} \times \mathrm{H} \times \sigma_{p} \% \mathrm{KGH}=\left[\frac{\mathrm{KGH}}{\mu}\right] \times 100 \%
$$

\begin{tabular}{|c|c|c|c|c|c|}
\hline Locations & Abbreviation & Latitude & Longitude & Altitude ( $\mathrm{m}$ asl) & Number of family \\
\hline Rinbo Panti, Sumatra, & SRP & $00^{\circ} 19^{\prime} \mathrm{N}$ & $100^{\circ} 05^{\prime} \mathrm{E}$ & 294 & 2 \\
\hline Kampar, Riau & SKR & $00^{\circ} 18^{\prime} \mathrm{N}$ & $100^{\circ} 57^{\prime} \mathrm{E}$ & 50 & 14 \\
\hline Ogan Komering Ilir, Sumatra & SOK & $03^{\circ} 12^{\prime} \mathrm{S}$ & $104^{\circ} 51^{\prime} \mathrm{E}$ & 23 & 11 \\
\hline Garut Selatan, Java & JGS & $07^{\circ} 26^{\prime} \mathrm{S}$ & $107^{\circ} 42^{\prime} \mathrm{E}$ & 628 & 8 \\
\hline Nusa Kambangan & JNK & $07^{\circ} 43^{\prime} \mathrm{S}$ & $108^{\circ} 55^{\prime} \mathrm{E}$ & 40 & 7 \\
\hline Alas Purwo, Java & JAP & $08^{\circ} 38^{\prime} \mathrm{S}$ & $114^{\circ} 21^{\prime} \mathrm{E}$ & 33 & 11 \\
\hline Batu Licin, Kalimantan & KBL & $03^{\circ} 19^{\prime} \mathrm{S}$ & $115^{\circ} 41^{\prime} \mathrm{E}$ & 47 & 4 \\
\hline Kapuas Tengah, Kalimantan & KKT & $01^{\circ} 00^{\prime} \mathrm{S}$ & $114^{\circ} 28^{\prime} \mathrm{E}$ & 147 & 2 \\
\hline Gowa, Sulawesi & CPG & $05^{\circ} 14^{\prime} \mathrm{S}$ & $119^{\circ} 35^{\prime} \mathrm{E}$ & 119 & 15 \\
\hline Pomalaa, Sulawesi & CPK & $04^{\circ} 03^{\prime} \mathrm{S}$ & $121^{\circ} 39^{\prime} \mathrm{E}$ & 210 & 22 \\
\hline Batu Hijau, Sumbawa & $\mathrm{NBH}$ & $08^{\circ} 58^{\prime} \mathrm{S}$ & $116^{\circ} 48^{\prime} \mathrm{E}$ & 53 & 8 \\
\hline Kuala Kencana, Papua & PKK & $04^{\circ} 24^{\prime} \mathrm{S}$ & $136^{\circ} 52^{\prime} \mathrm{E}$ & 107 & 1 \\
\hline
\end{tabular}

Where $\mathrm{KGH}=$ genetic gain expectation which is obtained using specific selection method; $\mathrm{I}=$ Selection Intensity at $60 \%-80 \%$ level; $\mathrm{H}=$ Heritability; $\sigma_{p}=$ phenotypic standard deviation.

Table 1. Provenance detail of N. cadamba and their geographical locations

Source: Sudrajat et al. 2016 
Phenotypic and genetic correlation was estimated from the component of variance and covariance as follows:

$$
\operatorname{RP}(x y)=\frac{\operatorname{covu}(x y)}{\sqrt{\sigma^{2} P+\sigma^{2} P(y)}} ; R g(x y)=\frac{\operatorname{covf}(x y)}{\sqrt{\sigma^{2} \mathrm{f}(x)+\sigma^{2} \mathrm{f}(y)}}
$$

Where $x=$ tree height; $y=$ diameter; $\sigma 2(x)$ and $\sigma 2 f(x)$ $=$ component of variance of phenotypic and genotypic product of x parameter; $\sigma 2 p(y)$ and $\sigma 2 f(y)=$ components of variance of phenotypic and genotypic product of $\mathrm{y}$ parameter; $\operatorname{COVP}(x y)$ and $\operatorname{COV} f(x, y)=$ components of covariance of phenotypic and genotypic product of $x$ and $y$ parameters, respectively, while $x$ and $y$ traits covariant component were calculated by formula:

$$
\operatorname{CoV} f(x, y)=0.5\left(\sigma_{\mathrm{f}(\mathrm{x}+\mathrm{y})}^{2}-\mathrm{o}_{\mathrm{f}(\mathrm{x})}^{2}-\sigma_{\mathrm{f}(\mathrm{y})}^{2}\right)
$$

Where $\sigma^{2}(\mathrm{x}+\mathrm{y})=x$ and $y$ traits variance component; $\sigma^{2}{ }_{\mathrm{f}(\mathrm{x})}=x$ traits variance component; $\left.\sigma_{\mathrm{f}(\mathrm{y})}^{2}\right)=y$ traits variance component.

\section{RESULTS AND DISCUSSION}

\section{Growth, wood quality, and genetic variation}

The measurements of height, diameter and wood quality in Table 2 showed variation among 105 families of white jabon. The average values range from $5.10-10.15 \mathrm{~m}$ for height, $6.67-15.30 \mathrm{~cm}$ for diameter, $2.30-3.62 \mathrm{~cm}$ for pilodyn, $0.66-0.82 \mathrm{~g} / \mathrm{cm}^{3}$ for wood density, $0.33-0.50$ for specific gravity, and $66-111 \%$ for moisture content. Significant effect of families and blocks were observed for height and diameter (Table 3). It means that the growth of white jabon in Parung Panjang is influenced not only by genetic factors, but also by environmental factors. Meanwhile, for wood quality in (Table 3) families and blocks affect pilodyn penetration, wood density, and specific gravity, while moisture content only significantly affected by blocks.

\section{Ranking of the best families}

Table 4 presents the ranked 10 best families for all traits. The best family for height was observed on CPK-22, while CPG-4 was for diameter, SOK-18 for penetration of pilodyn, JAP-6 for density, and KKT-6 for specific gravity.

\section{Genetic parameters}

Genetic correlation between height and diameter with pilodyn penetration were 0.077 and 0.498 , respectively (Table 5). The diameter and pilodyn penetration showed negative correlation, as well as between pilodyn with wood density and specific gravity (-0.937. Meanwhile, the diameter with wood density $(-0.292)$ and specific gravity showed positive correlation, which was $0.483,0.211$, respectively. These correlations were important in plant breeding program, to determine which of these traits the selection is based on, in order to produce white jabon with the best growth and wood quality.

Estimates of individual heritability (hi) were lower than family heritability (hf) (Table 6). The family heritability was found higher for height (0.69) than diameter (0.51), while for wood density was 0.59 , followed by penetration of pilodyn (0.46). Estimation of heritability in this study ranged from 0.1-0.69, of which values were considered as medium to high category. According to Cotterill and Dean (1990), when the value of heritability $<0.1$ is considered as low, value between $0.1-0.3$ is moderate, and more than 0.3 is high.

Total estimated genetic gain was present in Table 6 . From three scenarios of selection, intensity presented the diameter had the highest total genetic gain of all observed traits, i.e. $8.274 \%, 6.745 \%$, and $4.996 \%$. A scenario of $80 \%$ selection intensity by leaving the best 84 families in each plot had the highest total genetic gain from the other selection intensities. At the $80 \%$ selection intensity the height, diameter, wood density, and specific gravity had high values, which were $5.476 \%, 8.274 \%, 0.571 \%$, and $0.594 \%$ except for pilodyn penetration, which had the lowest value of $0.463 \%$.

Table 2. Growth and wood quality performance of various families in white jabon progeny test

\begin{tabular}{lcccc}
\hline Variable & Mean & SD & Min. & Max. \\
\hline Height $(\mathrm{m})$ & 7.93 & 1.03 & 5.10 & 10.15 \\
DBH $(\mathrm{cm})$ & 10.08 & 1.43 & 6.67 & 15.30 \\
Pilodyn penetration $(\mathrm{cm})$ & 2.59 & 0.15 & 2.30 & 3.62 \\
Wood density $(\mathrm{g} / \mathrm{cm} 3)$ & 0.74 & 0.03 & 0.66 & 0.82 \\
Specific gravity & 0.41 & 0.02 & 0.33 & 0.50 \\
Moisture content $(\%)$ & 85.47 & 9.78 & 66 & 111 \\
\hline
\end{tabular}

Table 6. Estimated heritabilities in white jabon progeny test

\begin{tabular}{lcc}
\hline Variable & $\begin{array}{c}\text { Individual } \\
\text { heritability- } \\
\left(\mathbf{h}^{2} \mathbf{i}\right)\end{array}$ & $\begin{array}{c}\text { Family } \\
\text { heritability- } \\
\left(\mathbf{h}^{2} \mathbf{f}\right)\end{array}$ \\
\hline Height $(\mathrm{m})$ & 0.4 & 0.69 \\
Diameter $(\mathrm{cm})$ & 0.2 & 0.51 \\
Pilodyn penetration $(\mathrm{cm})$ & 0.16 & 0.46 \\
Wood density $\left(\mathrm{g} / \mathrm{cm}^{3}\right)$ & 0.27 & 0.59 \\
Specific gravity & 0.1 & 0.35 \\
\hline
\end{tabular}

Table 3. Mean square for growth and wood quality in white jabon progeny test

\begin{tabular}{lccccccc}
\hline $\begin{array}{c}\text { Source of } \\
\text { variation }\end{array}$ & $\begin{array}{c}\text { Degrees of } \\
\text { freedom }\end{array}$ & Height $(\mathbf{m})$ & Diameter $(\mathbf{c m})$ & $\begin{array}{c}\text { Pilodyn } \\
\text { penetration }(\mathbf{c m})\end{array}$ & $\begin{array}{c}\text { Wood density } \\
\left(\mathbf{g} / \mathbf{c m}^{\mathbf{3}}\right)\end{array}$ & Specific gravity & $\begin{array}{c}\text { Moisture } \\
\text { content }(\boldsymbol{\%})\end{array}$ \\
\hline Fam & 104 & $8.977^{* *}$ & $16.848^{*}$ & $0.235^{* *}$ & $0.010^{* *}$ & $0.004 * *$ & $769.906 \mathrm{~ns}$ \\
Block & 4 & $258.872 * *$ & $379.9715^{* *}$ & $0.425 *$ & $0.239 * *$ & $0.079 * *$ & $11113 * *$ \\
Error & 875 & 3.851 & 10.175 & 0.168 & 0.005 & 0.002 & 501.307 \\
\hline
\end{tabular}

Notes: $* *=$ significant at $p<0.01, *=$ significant at $p<0.05, \mathrm{~ns}=$ not significant 
Table 4. Ranking of the best families for growth and wood quality in white jabon progeny test

\begin{tabular}{|c|c|c|c|c|c|}
\hline Ranking & Height (m) & Diameter (cm) & Pilodyn penetration $(\mathrm{cm})$ & Wood density $\left(\mathrm{g} / \mathrm{cm}^{3}\right)$ & Specific gravity \\
\hline 1 & CPK-22 (10.15) & CPG-4 (15.30) & SOK-18 (2.30) & JAP-6 (0.84) & CPK-7 (0.57) \\
\hline 2 & SOK-6 (10.05) & CPK-16 (12.73) & SOK-13 (2.31) & CPG-10 (0.81) & KKT-6 (0.50) \\
\hline 3 & JAP-14 (10.02) & SKR-12 (12.72) & KBL-3 (2.33) & CPG-2 (0.81) & SOK-4 (0.48) \\
\hline 4 & JGS-11 (9.98) & CPK-22 (12.23) & CPK-12 (2.34) & KKT-6 $(0.81)$ & CPK-16 (0.47) \\
\hline 5 & SKR-12 (9.83) & SKR-11 (12.17) & SOK-14 (2.36) & KKT-2 (0.80) & KKT-2 (0.46) \\
\hline 6 & NBH-10 (9.64) & CPG-8 (12.01) & CPK-3 (2.39) & CPK-13 (0.80) & SKR-8 (0.44) \\
\hline 7 & JAP-17 (9.63) & PKK-1 (11.86) & CPG-1 (2.40) & JAP-2 $(0.80)$ & JNK-7 (0.44) \\
\hline 8 & SOK-15 (9.62) & SKR-3 (11.83) & CPG-9 (2.42) & CPG-9 (0.80) & CPG-2 (0.43) \\
\hline 9 & JAP-4 (9.39) & SRP-1 (11.76) & CPK-4 (2.44) & SKR-8 (0.79) & JGS-4 (0.43) \\
\hline 10 & JNK-1 (9.38) & JGS-11 (11.73) & CPG-3 (2.44) & SOK-13 (0.79) & CPK-11 (0.43) \\
\hline
\end{tabular}

Note: SRP (C.N. Rimbo Panti, West Sumatera), SKR (Kampar, Riau), SOK (Ogan Komering Ilir, South Sumatra), JGS (Garut-West Java), JNK (C.N. Nusa Kambangan), JAP (Alas purwo, East Java), KKT (Kapuas Tengah, Central Kalimantan), KBL (Batu Licin, South Kalimantan), CPG (Gowa, South Sulawesi), CPK (Pomalaa, Sulawesi), NBH (Batu Hijau, Sumbawa), PKK (Kuala Kencana, Timika, Papua)

Tabel 5. Genetic (upper diagonal) and phenotype (lower diagonal) correlation coefficients among traits in white jabon progeny test

\begin{tabular}{|c|c|c|c|c|c|c|}
\hline Variable & Height & Diameter & $\begin{array}{c}\text { Pilodyn } \\
\text { penetration }\end{array}$ & $\begin{array}{c}\text { Wood } \\
\text { density }\end{array}$ & $\begin{array}{l}\text { Specific } \\
\text { gravity }\end{array}$ & $\begin{array}{c}\text { Moisture } \\
\text { content }\end{array}$ \\
\hline Height & & 0.597 & 0.077 & -0.471 & -0.319 & -0.229 \\
\hline Diameter & 0.692 & & -0.498 & 0.483 & 0.211 & -0.691 \\
\hline Pilodyn penetration & 0.011 & -0.084 & & -0.292 & -0.937 & 0.882 \\
\hline Wood density & 0.174 & -0.031 & -0.107 & & 0.979 & -0.170 \\
\hline Specific gravity & 0.029 & 0.168 & -0.121 & 0.529 & & -0.620 \\
\hline Moisture content & -0.174 & -0.213 & 0.16 & 0.231 & -0.645 & \\
\hline
\end{tabular}

Table 7. Estimates of total genetic gain for growth and wood quality in white jabon progeny test

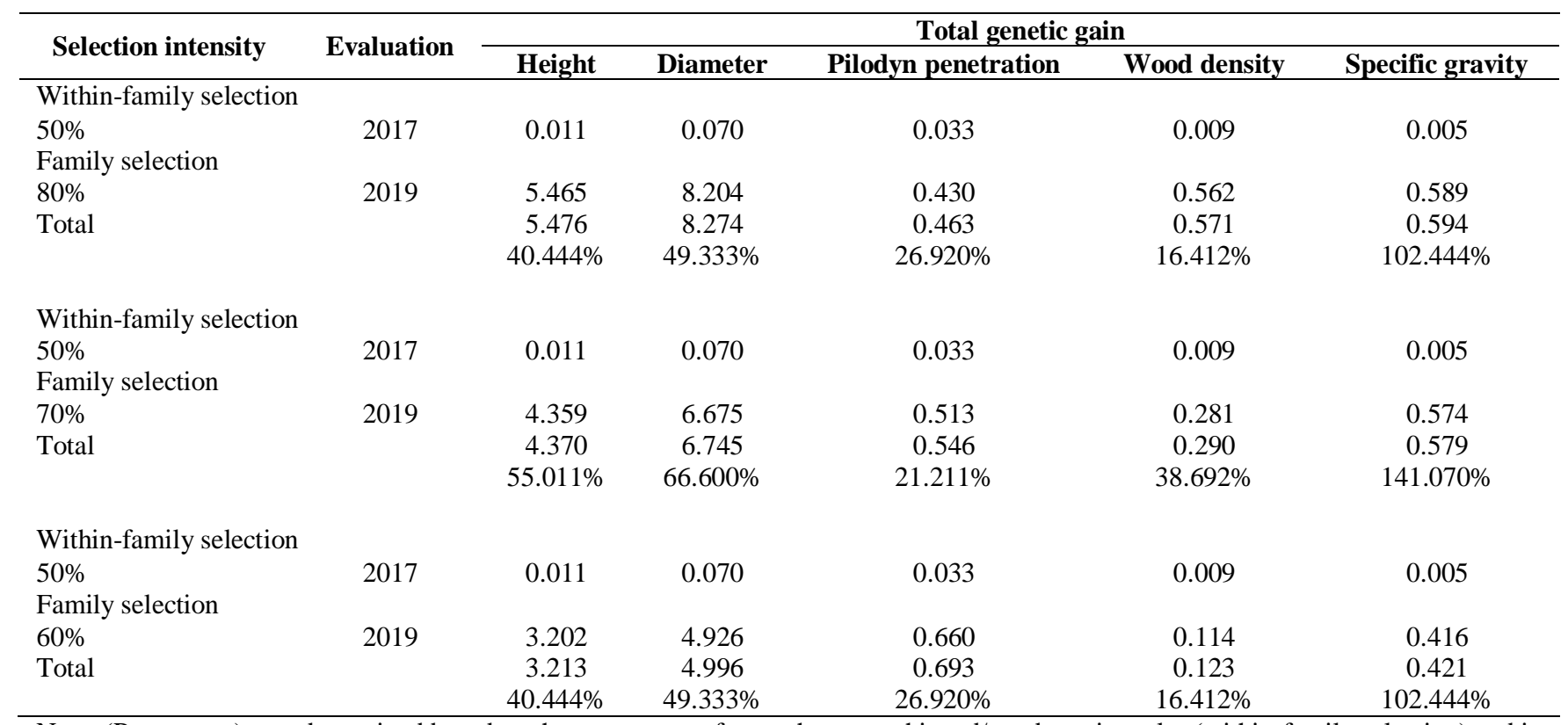

Note: (Percentage) was determined based on the percentage of trees that were thinned/cut down in a plot (within-family selection) and in a block (family selection) 


\section{Discussion}

Growth (height and diameter) and wood quality (pilodyn penetration, wood density, specific gravity, and moisture content) of white jabon showed variation among families. According to Zobel and Talbert (1984), variation in a plant can occur between species, geographical region (provenance), site to grow, and individual within-family. The growth value of the height and diameter of white jabon in this study was better than the result of Junaedi (2018) for the growth of 4-year-old white jabon in Riau, the average value was $4.17 \mathrm{~m}$ for height and $5.15 \mathrm{~cm}$ for diameter. This difference was caused by different genetic material, site condition, and silviculture treatments. The difference in growth of white jabon in different sites also was reported by Krisnawati et al. (2011) and Seo et al. (2015).

Significant effect on families and blocks were observed for height and diameter, these results were similar with the research conducted by Sudrajat et al. (2016), Wardani (2017) and Anna et al. (2018) on the same test-plot at 12, 24 , and 36 months of the age. This provides the information that the growth of the height and diameter of white jabon in Parung Panjang from the beginning to the age of 54 months was consistently varied among families throughout these years. The variation among families in the progeny test is due to the far distance of the origin of the genetic material used (Mashudi and Baskorowati 2015). According to Zobel and Talbert (1984), geographical differences affect genetic traits, a species having a broad genetic basis had a high ability to adapt in diverse environments. This result was similar with previous studies who examined genetic diversity of the same genetic material of white jabon using AFLP marker revealed that the genetic material had high genetic diversity (Sudrajat et al. 2015) and most of variation is contributed by genotype variation (Sudrajat 2016).

Some superior families were found in this study. Families from CPK-22 (Pomalaa, Sulawesi) and SKR-12 (Kampar, Riau) were the best and stable families in Parung Panjang. This result was proven as both families always included in the ranked as the 10 best families. The CPK-22 family has gained the rank for all observed traits, so that it can be considered as parent trees for producing superior seeds. The families also can be a candidate for developing the superior clone which propagated by vegetative techniques. Rank of family could be able a consideration for thinning selection in conversion of the progeny test to seedling seed orchard of white jabon.

Phenotypic and genetic correlations between the plant growth and wood quality characteristics indicated the possibility to use one or some characteristics of growth and wood quality characteristics to make selection more efficient. The diameter and pilodyn penetration showed negative correlation indicating that when the diameter is increased it will have implication for the low penetration of pilodyn. Penetration of pilodyn will be lower as the density and specific gravity increased with the increasing diameter. As this study showed diameter showed positive correlation with wood density and specific gravity. According to Erwi et al. (2015), positive relationship among one trait and the other traits showed that both traits can be considered together, because when there was increased of one trait, there will be increase in the other. Negative correlation between pilodyn penetration with diameter, wood density, and specific gravity was desired relationship, when to do improvement for growth traits and wood quality will influence the low of pilodyn penetration. Genetic correlation values were higher than the phenotypic correlation, indicating that all traits were influenced by high additive genes. According to Cheverud (1988), a trait that had a profitable correlation with other traits can be used as candidate selection if its genetic correlation was higher than phenotypic correlation. Negative correlation between pilodyn penetration showed that pilodyn penetration can be used for measuring wood density. Negative correlation results between pilodyn penetration with wood density and specific gravity also were reported by Kien (2008) and Wei and Borralho (1997) in Eucalyptus urophylla.

Lower estimates of individual heritability (hi) than family heritability (hf) was in accordance with Zobel and Talbert (1984) statement that the value of family heritability is usually greater than individual heritability, so that the tree plot can be reduced. According to Sudrajat (2015), if the family heritability value is higher, then the selection among families is done to obtain a higher genetic gain. High heritability values for a trait are more influenced by genetic factors than environmental factors (Putri et al. 2009). The heritability values change with increasing age. The heritability of white jabon aged 12, 24, and 36 months in Parung Panjang was classified as moderate to very low, then increased at the age of 54 months. According to Zobel and Talbert (1984), the value of heritability will always change or differ according to time (plant age), site and species.

The progeny test of white jabon was evaluated in 2017 by mass selection with selection intensity of $50 \%$, the selection was done by removing 2 trees that had bad performance from each tree plot. The next selection by removing one more individual will maintain only one best tree from each tree plot, then followed by the last selection among families. This study tried to determine the selection intensity and select traits which will be used for the next selection program, also to determine the prediction of total genetic gain, which will be the results of the individual selection done in 2017, following another individual selection and family selection in 2019. Calculation of total genetic gain at various selection intensities was done to find out how much growth could have occurred after family selection is carried out. Selection simulation is done using $80 \%$ intensity (retaining 84 best families), $70 \%$ intensity (retaining 74 best families) and 60\% (retaining 63 best families). Genetic gain values were influenced by heritability values. Although the diameter had a lower heritability value than height (Table 6), but the diameter had high genetic diversity (Table 2). According to Syukur et al. (2011), the selection will be effective and showed high genetic gain if that trait had extensive genetic diversity and high heritability value. A trait who has a high 
genetic diversity will produce varied growth it due to environmental influences, so that for improving the plantation can proper silvicultural treatment such as environmental manipulation. Therefore the diameter can be made candidate for selection to produce high genetic gain.

The low value of pilodyn penetration was beneficial, because the aim of this study was to determine the selection intensity which could increase growth and wood quality with a small pilodyn penetration value. Based on these results the next selection is carried out by leaving 84 of the best families in each plot. The amount of families left behind was appropriate by forestry minister's regulation number P.1/ -II/2009 that the development of seed orchards must leave a minimum of 25 families. Candidate selection trait that can be used is diameter, if viewed from the results of correlation on (Table 5) diameter had negative correlation with pilodyn penetration and had positive correlation with wood density and specific gravity, it means that if the selection is based on diameter it will produce white jabon wood with the best growth and wood quality. In conclusion, the growth of 54 months white jabon showed significant differences among families, except for moisture content. Heritability values were in the medium to high category, with high heritability estimates were found for height (0.4-0.69) and basic density (0.270.59 ). Using $80 \%$ selection intensity by leaving the 84 best families in each block will produce a higher total genetic gain, using diameter as the basis for next selection program. Pilodyn penetration had negative correlation with growth trait (diameter) and wood quality (wood basic density and specific gravity), which is desirable. And useful for assessing wood quality, especially for wood basic density using a pilodyn.

\section{ACKNOWLEDGEMENTS}

We appreciate USAID through SHERA programCentre for Development of Sustainable Region (CDSR) for facilitating this research. In the year 2017-2021, CDSR is led by Center for Energy Studies - UGM. Authors also thank the BPTPTH, Forestry of Faculty IPB University and SEAMEO BIOTROP.

\section{REFERENCES}

Anna N, Siregar IZ, Supriyanto, Karlinasari L, Sudrajat DJ. 2018. Genetic variation of growth and its relationship with pilodyn penetration on provenance-progeny trial of jabon (Neolamarkcia cadamba (Roxb) Bosser) at Parung Panjang, Bogor. J. Ilmu Teknol. Kayu Tropis 16 (2). [Indonesian]

Burger JA. 2009. Management effects on growth, production and sustainability of managed forest ecosystems: Past trends and future directions. For Ecol Manag 258: 2335-2346.

Cheverud JM. 1988. A comparison of genetic and phenotypic correlations. Evaluation 42 (5): 958-968.

Cotteril PP, Dean CA. 1990. Successful Tree Breeding with Index Selection CSIRO Division of Forestry and Forest Product, Australia.

Erwi L, Muin A, Burhanuddin. 2015. Test of heritability of (Aquilaria malaccensis Lamk) for four years on the Forestry Agency Of Regency Ketapang. Jurnal Hutan Lestari 3 (2): 300-312. [Indonesian]

Falconer DS. 1981. Introduction to Quantitative Genetic. 2nd ed. Longman Inc, New York.
Falconer DS, Mackay TFC. 1996. Introduction to Quantitative Genetics $4^{\text {nd }}$ Edition. Addison Wesley Longman Ltd. New York.

Fox JED. 1971. Anthocephalus chinensis, the Laran Tree of Sabah. Econ Bot 23 (23): 221-233.

Gaspar MJ, Lousada JL, Rodrigues JC, Aguiar A, Almeida MH. 2009. Does selecting for improved growth affect wood quality of Pinus pinaster in Portugal. For Ecol Manag 258: 115-121.

Greaves BL, Borralho NMG, Raymond CA, Farringto A. 1996. Use of a pilodyn for the indirect selection of basic density in (Eucalyptus nitens). Canadian J For Res 26 (9): 1643-1650.

Gultom RN, Sulaeman R, Budiani ES. 2017. Utilization of Jabon wood waste and palm fiber waste as raw material for charcoal briquette. Jom Faperta UR 4 (1). //jom.unri.ac.id/index.php/JOMFAPERTA/article/view/16933/16349 [Indonesian]

Hansen CP. 2000. Application of the pilodyn in forest tree improvement. Danida Forest Seed Center, Denmark.

Hartanto H. 2011. Pola Budidaya Jabon. Brilliant Books, Yogyakarta. [Indonesian]

Junaedi A. 2018. Growth of Anthocephalus cadamba Miq. in marginal land ultisol soil in Riau. Jurnal Pemuliaan Tanaman Hutan 12 (1): 5163. [Indonesian]

Jun WS, Min XJ, You LG, Vuokko R, Hua LZ, Qi LB, Wei W. 2010. Use of the pilodyn for assessing wood properties in standing trees of Eucalyptus clones. J For Res 21 (1): 68-72.

Irawan US, Purwanto E. 2014. White jabon (Anthocephalus cadamba) and red jabon (Anthocephalus macrophyllus) for community land rehabilitation: Improving local propagation efforts. Agric Sci 2 (3): 36-45.

Kallio MH, Krisnawati H, Rohadi D, Kanninen M. 2011. Mahogany and kadam planting farmers in South Kalimantan: The link between silvicultural activity and stand quality. Small-scale For 10: 115-132.

Kien ND, Jansson G, Harwood C, Almqvist C, Thinh HH. 2008. Genetic variation in wood basic density and pilodyn penetration and their relationships with growth, stem straightness and branch size for Eucalyptus urophylla S.T. Blake in Northern Vietnam. New Zealand J For Sci 38 (1): 160-175.

Krisnawati H, Kallilo M, Kanninen M. 2011. Anthocephalus cadamba Miq.: Ekologi, silvikultur dan produksi. Center for International Forestry Research, Bogor. [Indonesian]

Langga IF, Restu M, Kuswinanti T. 2012. Optimization of temperature and length of incubation in extracting Bitti Plant (Vitex cofassus Reinw.) DNA and genetic variation analysis with RAPD-PCR. J Sains Teknologi 12 (3): 265-276. [Indonesian]

Malik MFEI, Abdelgadir AY. 2015. Effect of growth rate on wood density of Eucalyptus camaldulensis wood of coppice origin grown in White Nile State Sudan. J For Prod Indust 4 (3): 2325-4513.

Martinez-Meier A, Gallo L, Pastorino M, Mondino V, Rozenberg P. 2011. Phenotypic variation of basic wood density in Pinus ponderosa plus trees. Bosque 32 (3): 221-226.

Mashudi, Baskorowati L. 2015. Estimation of genetic parameters at two years old of Alstonia scholaris progeny trial at Gunungkidul Yogyakarta. Jurnal Pemuliaan Tanaman Hutan 9 (1): 1-11. [Indonesian]

Moya MR, Tomazello M. 2007. Wood density and fiber dimensions of Gmelina arborea in fast growth trees in Costa Rica: relation to the growth rate. Investigación Agraria. Sistemasy Recursos Forestales 16 (3): $267-276$.

Muga M, Owino F, Ruigu S. 2014. Variation in wood density and strength properties among Markhamia lutea (Sprague) half-sib families from Western Kenya. Intl J Appl Sci Tech 4 (4): 221-228.

Nocetti M, Brunetti M, Ducci F, Romagnoli M, Rozenberg P, Santi F. 2012. Phenotypic correlations among wood properties and growth in wild cherry plantations. Bio Resour 7 (3): 3160-3174.

Pathauer PS, Lopez GA, Gelid PE. 2004. Genetic parameter for growth, pilodyn penetration, and tree form in Eucalyptus dunnii. In: Borralho, $\mathrm{N}$, et al. Eucalyptus in a Changing World. Proc IUFRO Conf., Aveiro 11-15 October 2004.

Putri LAP, Sudarsono H, Aswidinnoor, Asmono D. 2009. Genetics performance and heritability estimations on yield component and $\beta$ carotene content of oil palm progenies. J Agron Indonesia 37 (2): 145-151.

Seo JW, Kim H, Chun JH, Mansur I, Lee CB. 2015. Silvicultural practice and growth of the jabon tree (Anthocephalus cadamba Miq.) in community forests of West Java, Indonesia. J Agr Life Sci 49 (4) 8193. 
Sudrajat DJ. 2015. Population diversity, provenance and adaptability test of (Neolamarckia cadamba (Roxb.) BOSSER). [Disertasi]. Institu Pertanian Bogor, Bogor. [Indonesia].

Sudrajat DJ, Siregar IZ, Khumaida N, Siregar UJ, Mansur I. 2015. Genetic diversity of white jabon (Anthocephalus cadamba Miq.) based on AFLP markers. Asia Pac J Mol Biol Biotech 2 (3): 224-231.

Sudrajat DJ. 2016. Genetic variation of fruit, seed and seedling characteristics among 11 populations of white jabon in Indonesia. For Sci Tech 12 (1): 9-15.

Sudrajat DJ, Siregar IZ, Siregar UJ, Nurhasybi, Mansur I, Khumaida N. 2016. Intraspecific variation on early growth of Neolamarckia cadamba Miq. in provenance-progeny tests in West Java Province. Biotropia 23 (1): 10-20.

Syukur M, Sujiprihati S, Yunianti R, Kusumah DA. 2011. Pendugaan ragam genetik dan heritabilitas karakter komponen hasil beberapa genotipe cabai. J Agrivigor 10: 148-156. [Indonesian]
Wardani IGAK. 2017. Growth performance white jabon (Neolamarckia cadamba (Roxb.) Bosser) on provenance-descendant test aged 24 month in Limbangan and Parung Panjang. [Hon. Thesis]. Institut Pertanian Bogor, Bogor. [Indonesian].

Wei XM, Borralho NMG. 1997. Genetic control of wood basic density and bark thickness and their relationship with growth traits of Eucalyptus urophylla in South East China. Silvae Geneticae 46: 245250.

Yudohartono TP. 2013. Growth characteristic of jabon from Sumbawa provenance at nursery and after planting. Jurnal Pemuliaan Tanaman Hutan 7 (2): 85-96. [Indonesian]

Zobel B, Talbert J. 1984. Applied forest tree improvement. Waveland Press, Illinois. 